\title{
Exploring Greek Education System's Ethnocentric Character In Modern Time
}

\author{
Maria Chalari \\ Institute of Education, UCL, UK \\ Thomas Georgas \\ Institute for Educational Research, Athens-Greece
}

\begin{abstract}
This paper aims to engage with issues around Greek national identity and in the light of the above, tries to demonstrate how Greek national identity responds to global pressures and how it is being fractured in an era of economic and humanitarian crisis and uncertainty. The purpose of this critical review of literature is not to simply present the crisis of the Greek national identity but to explore the tensions and the competing relations between national, European, cosmopolitan, religious and racial identities in contemporary Greece at a time of rapid socioeconomic change and in the face of the declining authority and legitimacy of the state. Moreover, the present critical review seeks to look into the reasons why Greek national identity not only persists to its traditionally pro-European character but also becomes more and more ethnocentric and racist. Although we may not be able to formulate straightforward answers to the above issue, looking at the Greek educational context and drawing attention to the crucial links, which exist between the Greek national education and the persisting ethnocentric character of the Greek national identity could probably help us understand and uproot some reasons of the aforementioned phenomenon.
\end{abstract}

Keywords: Greece, education system, identity

\section{Introduction}

The aim of this critical review of literature is to engage with issues around Greek national identity and to indicate how Greek national identity is being fractured in an era of socioeconomic crisis. The purpose of the paper is to look into the reasons why Greek national identity not only persists to its traditionally pro-European character but also becomes more and more ethnocentric and racist, and to draw attention to the crucial links, which exist between the Greek national education and the aforementioned phenomenon.

The paper begins with a discussion about the historical development of 
nationalism in the $18^{\text {th }}$ and $19^{\text {th }}$ centuries and the emergence of the Greek nation state in the $19^{\text {th }}$ century. Next, it presents some important features of the Greek national education system paying attention to its role in the formation of Greek national identity. It continues by looking at some aspects of Greek society after the 1980s and at the latest political and economical changes and their implications for Greek society.

Therefore in relation to its purpose, the paper focuses on the relation between the education system and the persisting ethnocentric character of Greek national identity. It also illustrates that if schools are to meet the new challenges that stem from the current era of economic and humanitarian crisis, they must change.

\section{The emergence of Greek National Identity}

\section{The emergence of the nation states in the $18^{\text {th }}$ and $19^{\text {th }}$ centuries}

The division of the world in nations seems to be natural, but it is not. The nation is one of the most successful and dangerous myths of modernity (Coulby, 1997), a myth that established in the $19^{\text {th }}$ century (Ostergaard, 2000). The nation is a modern phenomenon in human history, and a socially and historically constructed product of particular and inevitably localised or regional, and 'historical conjunctures' (Hobsbawm, 1990, p. 5). To be correct, the modern phenomenon is not the nation, but the new-shared political concept of it, its contemporary meaning. The term 'nation' has been defined by Guibernau and Goldblatt (2000, p. 125) as 'a named people who acknowledge a shared solidarity and identity by virtue of a shared culture, history and territorial homeland'. The nation-states of the modern epoch no longer refer to a territorial kingdom as they used to do before the French Revolution, but to a political collectivity (Ostergaard, 2000).

Authors such as Ernest Gellner (1983), Benedict Anderson (1991), Anthony Smith (1991), or Charles Tilly (1992) have demonstrated the links between modernity as a structure of thought, and the nation as an ideological system. Anderson (1991) argues that the appearance of the 'imaginary communities' followed the abolition of the traditional societies, where the religion had a cohesive role, and it is related with the emergence of the local languages and the development of the communication technology. Others (Grant, 1997; Held, 1992) have suggested that nations started forming after the Treaties of Westphalia or of Versailles (Ostergaard, 2000). According to Gellner (1983) the development of industrialization and the cultural homogeneity, which was created, played important role in the formation of the nation states.

There is a separation of the nations at least to two models, the 'Western' and the 'Eastern' (Smith, 2000). These two models appeared in different historical contexts. The Western or civic model was state defined 
and inclined to highlight the centrality of a national territory, a common system of laws and institutions and the importance of a mass, civic culture binding the citizens together. The Eastern or ethnic model, by contrast, tended to emphasize the genealogy, the folk element, the native culture and language, customs, religions and rituals (Smith, 2000). Although contemporary theorists of nationalism, such as Smith (2000), note that the above division of nationalism is idealized and does not reflect the historical reality (Kuzio, 2002), they still think that there is something valid and useful in it, specially when we want to study the development of nationalism in particular countries (Shulman, 2002).

Maybe by using the civic and the ethnic model division we could shed light on the reasons why the revival of nationalism in the mid 1980s has resulted in governments and citizens of some countries to reconsider the meaning of nationality, inducing a more inclusive and multicultural conception of 'the nation' and in other countries, such as Greece, it has fuelled xenophobic backlash.

\section{The emergence of the Greek nation state in the $19^{\text {th }}$ century}

The emergence of the Greek nation state happened in the $19^{\text {th }}$ century (Stamelos, 2000) and was a result of a revolutionary uprising with the demand of the national revival (Tsoukalas, 1982). The Greek national identity was invented and constructed in the turbulent and doubtful period (1922-1974) after the collapse of the 'Great Idea' (1922) (Tsoukalas, 1982). The term 'Great Idea' appears for the first time in Kolletis speech to the first Greek parliament (1844). This term refers to the expectation of some Greek politics (Kolletis 1844, Deligiannis 1890, Venizelos 1911) that some regions, which were under Turkish sovereignty, would enter the Greek state of the 1830. After the Asia Minor destruction (1922), as the treaty of Lausanne brings to an end this expectation, the 'Great Idea' collapses and the 'Greek' nation is forced to accept the imposed reality, the new narrow boundaries of 'its' land (Skopetea, 1988).

Historical evidence shows that nationalism has been brought to Greece by the Greek speaking Diasporas. As it happened with most national geneses the Greek-speaking intellectuals of the 18th and 19th centuries were greatly influenced by the spirit of the Enlightenment and carried it with them translated to the geographical, social and cultural environment of what was to become the Modern Greek kingdom. The above intellectuals believed in the superiority of the Greek nation and the Greek language at least in the Balkan Peninsula and Asia Minor, the need to hegemonize the Balkans with an educated class of Greek speakers, and the need to expand the Greek state (Chrysoloras, 2004, p.16). Many of them were clerics and understood Enlightenment through the Orthodox dogma (Chrysoloras, 2004). 
The Greek nationalist discourse was structured around a series of nodal propositions that prevail till today: a) there is a unified history of one Greek nation starting from the pre-Homeric era, through to Classical Greece, the Hellenistic epoch, the Byzantium, and continuing in modern Greece. b) The nation is bound together by geography, history, language, and religion. c) Being Orthodox Christian is an almost necessary pre-condition for being Greek. d) The Greek nation is superior to almost any other nation in the world since Greeks are the heirs of almost all the great civilizations of the West (Ancient Greek, Hellenistic, Eastern Roman/Byzantium) (Chrysoloras, 2004, p.17).

The preceding nationalistic discourse might help us unravel the difficulties Greek national identity faces in the current era of socioeconomic crisis with regard to the European Union project and ideas about cosmopolitanism, its evolution, its struggles, the nature of its challenges and tensions and the empowerment of its ethnocentric and racist sentiment.

\section{The role of the Greek National Education System in the formation of Greek national identity}

The national education systems first appeared in post-revolutionary Europe (Green, 1997) in the late eighteenth century as being instruments of state formation and useful tools for developing a common national identity within specific geographical borders (Wiborg, 2000). Today, three centuries later the national education systems still hold this role even though many other agents of socialization such as family, peer groups, mass media etc. influence students as well. Education systems everywhere, through their subjects, their textbooks and other activities initiate young people into the traditions and cultures of their society and promote cohesion and a sense of national identity (Goodings, 1987).

The aims and the role of education in the formation of national identity differ from one country to another and they are determined substantially by the process and the purpose of the formation of each nation state (Avdela, 1998). The Greek nation belongs to the 'Eastern' model of the nations which attended to emphasize the genealogy of their people (Smith, 2000), and its formation refers to a cultural plan, which was based on a glorious and distant past, without geographical boundaries (Tsoukalas, 1982). As a result, Greek national education system aims to educate and initiate Greek students with a 'natural' and 'normal' way into the traditions and culture of their society (Stamelos, 2000).

The Greek education system is particularly centralized and seeks to cultivate Greek national identity throughout its curriculum and throughout its compulsory textbooks, which are state-endorsed (Coulby, 2000; Avdela, 1998; Coulby \&Jones, 1995; Massialas \& Flouris, 1994). The Pedagogical Institute as a representative of the government writes the curriculum and the 
textbooks. The Institute takes advices from academics and teachers when it draws up particular textbooks, but the last word on content remains in the Ministry of National Education and Religions. The teachers in schools must follow the school curriculum and teach each subject exclusively from the Pedagogical Institute textbooks (Avdela, 1998).

The curriculum and the textbooks, especially in subjects such as History, Greek Language and Geography promote Greek nationalism by presenting an image of the Greek nation, which is based on the common agreement of its homogeneity and superiority (Tsoukalas, 1982). They also attempt to identify the modern nation state, 'via Byzantine Orthodoxy, with the city-states of the fourth century BC and thus with Hellenic civilization' (Psomiades \& Thomadaki, 1993 quoted in Coulby, 2000, p. 92). The curriculum and the textbooks see the Greeks as the fountainhead of European civilization and focus on other states only through the teaching of the wars, expansionary policies in the past and hostile stances in the present (Avdela, 1998).

As Coulby (2000, p. 92-93) argues, the curriculum 'in attempting to bury the state's recent history of internal and external warfare and conflict beneath a homogenous Greek and Orthodox identity, only exacerbates tensions with internal minorities and bordering states'. Consequently students in Greece are exposed and become acquainted with other countries, as well as with the concept of Europe only in the context of warfare and hostility (Flouris, 1995). It might be extreme to indicate that the Greek national education system encourages hostility and warfare; nonetheless it may be said that it undoubtedly does remarkably little to inspire conciliation and peace.

\section{The Greek society after the 1980s}

The Greek society after the entrance of Greece in the European Union

The entrance of Greece in the European Union (EU) brought the country closer to the 'European miracle' (Beck, 2005). The political project of the creation of the EU and the European citizen attempted to turn enemies of the past to neighbours by dispelling from the horizon of Europe the threat of violence as a political option, whether between member states or against supranational institutions. The European Union also aimed to ensure the health of the member states and the economy, effectively dealing with unemployment, and encouraging a lively democracy through a cosmopolitan viewpoint (Beck, 2005).

Soon after joining the European community in 1981, the Greek government aimed to introduce secularisation, modernization measures and increase Greece's standard of living, and made considerable steps towards this direction, liberalising the economy, and trying to replace the old clientist 
politics with an effective bureaucracy. Greece also became the recipient of many grants from the EU to strengthen its agricultural sector and build public works projects hoping to enhance economic growth (Dimitrakopoulos \& Passas, 2004). However, even with the European Union's financial assistance Greece stayed behind many of its fellow EU members and remained one of the least economically developed member countries in the European Union. In January 2001 Greece joined the EU's single currency (the euro), thereby allowing the European Central Bank govern its economy as the sole currency issuing institution.

Although many Greeks were positive towards the EU motivated mostly by economic advantage rather than a desire for deeper political and cultural convergence, a large part of the Greek population criticised the European Union concentrating on the cultural rather than the political or economic aspects of the European unification, and felt more and more estranged from the new westernised 'image' of Greece. Besides, the Greek attitude towards the West has always been equivocal, and the functioning of western-type institutions has often been disharmonious, if not always problematic (Chrysoloras, 2004). Many Greek people thought that the new European order undermined the role of national culture and the socializing of the state and family and saw the European Union as a threat against their imaginary collective identity. Those ideas have in effect prevented the full cultural and political integration of the country into the EU and its institutions.

Under such social circumstances the nationalist discourse and especially that of the Greek Church found a fruitful background in order to develop. The Church presented itself as a cultural opponent to the forces of assimilation and homogenisation and the Greeks identified themselves strongly with it maybe as a reaction to the abovementioned 'threats'. Orthodoxy until today remains a distinguishing characteristic of Greece, which has given and continues to give the impression of stability in a nation increasingly insecure about its identity (Chrysoloras, 2004).

In short, Greece because of its persistent ethnocentrism expressed in recent decades as exaggerated patriotism and xenophobia remained a largely pro- European country. The Greek case is an example, which demonstrates that the forces of Westernization and European integration do not automatically make weaker the forces of nationalism in Europe (Chrysoloras, 2004). Maybe it is because the Greeks don't feel secure and confirmed in their national dignity. As Beck (2005, p.114) argues, the more secure and confirmed Europeans feel 'the less they will shut themselves off in their nation-states and the more resolutely they will stand up for European values in the world and take up the cause of others as their own'. 


\section{The Greek society after the settlement of waves of immigrants in the period following the 1990s}

The entrance and settlement of waves of immigrants in many countries, especially after the nineteenth century, is a phenomenon that has given a diverse character to many societies in different countries all over the world (Lynch \& Simon, 2003). People from different cultural, religious linguistic, and ethnic backgrounds have ended up living and coexisting in places and circumstances dissimilar to those that they were used to. Greece is one of these European countries that as a result of immigration have significantly and irreversibly seen its demography changed in social, cultural, economic, ethnic, racial and religious terms (Stratoudaki, 2008).

During the period following the 1990s, Greece not only witnessed an impressive return of nationals to their homeland, but also experienced a shift from a traditionally sender country to a main destination country for immigrants from Central and Eastern Europe and the former Soviet Union (Rozakis, 2001). Rapid demographic changes that took place during the last two decades led to an increasing participation of immigrant people in Greek society.

This fact implied growing complexity, uncertainty and unpredictability in the Greek society, affected seriously its composition, which became progressively more heterogeneous and in turn affected the Greek national identity, which grew more unconfident and xenophobic. A vast amount of the Greek population expressed both antipathy and fear towards the immigrants, who were generally seen as the main cause of the significant rise of criminality in Greece (Stratoudaki, 2008).

\section{The latest political and economical changes in Greece and their implications for Greek society}

Financial crashes are as old as the markets themselves. Since the global economic crisis of 1929, it has been obvious that they influence everyone and can have catastrophic effects especially for politics (Beck, 2009; Levitas, 2000). When the global financial downturn struck, Greece was badly prepared after years of profligacy, unrestrained spending, cheap lending, hosting the expensive Olympic games in 2004 and after failure to implement financial reforms. By the end of 2009, the Greek economy faced the highest budget deficit and government debt to GDP ratios in the European Union, which led to rising borrowing costs, ultimately resulting in a severe economic crisis, maybe one of the worst in its history (Romanias, 2009).

Greece's fiscal and economic problems left the country struggling against unemployment and striving to pay its bills. The government in order to avoid a downward spiral has requested and agreed to a rescue package 
from the EU, the International Monetary Fund and the European Central Bank. It has also started slashing away at spending and implemented austerity measures that aim at reducing the deficit. It has hiked taxes on fuel, tobacco and alcohol, raised the retirement age by two years, imposed public sector pay cuts, closed schools and public hospitals and applied tough new tax evasion regulations; thousands of people have lost their jobs and more releases are on schedule (Vayanos, Meghir, \& Vettas, 2010).

The severe budget cuts and savage measures adopted by the Parliament have led workers nationwide to stage strikes closing airports, government offices, courts and schools, more than 500,000 Greeks to rally in central Athens to denounce politicians, bankers and tax dodgers, and a large number of Greek people to abandon the country and emigrate in search of better working and living conditions to the USA, Australia and other parts of Europe.The Greek society is not willing to accept austerity measures, already showing dissatisfaction and public unrest. Reformism in Greece has been met with protests, some of them quite violent, fortified by the belief of many Greeks that the crisis is being manipulated by foreign forces such as the European central bankers and other financial speculators (Pappas, 2010).

\section{Greek National Identity and the Greek Education System in the Age of Austerity}

\section{Greek National Identity in the Age of Austerity}

Linked to the economical changes is a change in views with regard to belonging and identities. Current debates include discussions about economics, fairness, concepts of national identity and perspectives on 'outsiders'. The crisis raises fundamental questions about how national identity can be identified, and what might be done to confirm it.

Greek national identity is increasingly growing more racist and xenophobic, a fact that reflects the deep identity crisis, which has come to underlie Greek society lately. Many Greek people have started becoming more and more racist as a result of their unemployment and their lower quality of life (Eurobarometer, 2008; EU-MIDIS, 2009; International Association for the Evaluation of Educational Achievement, 2011). Incidents of racial violence against migrants and asylum-seekers have increased the last six months particularly in Athens (Amnesty International, 2011).

The media, because of the sheer multiplicity of the forms in which they appear and because of the rapid way in which they move through daily life routines, (Appadurai, 1996), occupy a key site for the monitoring of the Greek self-imagining and the antagonistic relationship with the 'others' in this era of socioeconomic crisis. By observing the pages of tabloid newspapers or the TV shows we can see that negative language and misinformation for the 'others' -that are not anymore only the immigrants 
from the surrounding Slavic and Balkan populations, but also the European Union- is very common.

Very common also is the use by protestors, commentators, politicians, bankers of the narrative of the All-seeing Public Economist (APE) for Greece, which goes like this: 'Greece is a poor but honest country... The present crisis is a symptom of its exploitation by the European 'centre', whose essential nature is to be rich and exploitative. We poor Greeks were duped into entering the EU and adopting the euro. The cunning union gave us grants for our honest labour. Eventually, we were sucked dry: but the centre's greed is boundless, and now they want to gain more through usury and, if bad comes to worse, political domination...'(Doxiadis, 2011).

The aforementioned narratives, which are very similar to the narratives that have been used since the emergence of the Greek nation state in the $19^{\text {th }}$ century, treat Greeks as immature children, ultimately irresponsible for their acts and their faults, who must demonise others rather than understand themselves. Moreover, they enslave them to their worst ethnocentric self (Doxiadis, 2011).

\section{The role of the Greek Education system in the persisting ethnocentric character of Greek national identity}

The education sector is probably one of the most sensitive and politically charged areas of public policy because of its important role in identity formation, national cohesion, national consciousness and its potential to prepare students for their roles as world citizens (Kenway \& Bullen, 2000). In Greece, although different policies taking in account the current deep transformations, the new social conditions and the increasing and changing diversity are proposed, these policies do not seem to tackle the problems of Greek society with sufficient breadth.

As a result the Greek education system fails to address in its policy and curriculum documentation the full implications of the recent political and economical changes and, as many other education systems around the world (Kiwan, 2008), it continues to propose a single national identity, even though it is acknowledging the presence of a plurality of nations, to be based on exclusion rather than inclusion and on ethnocentrism rather than multiculturalism, and to be racist and nationalistic (Stratoudaki, 2008).

Relevant studies about the Greek education system and its role in the formation of the Greek national identity in the present rapidly changing era show that the Greek education system seeks to rationalize the curriculum and textbooks (Stratoudaki, 2008). But even if the curricula and books have improved being more tolerant and understanding to 'others', they still present an ethnocentric national history and tend to be introvert; they are still conservative and oblivious towards matters concerning religion or other 
nationalities, those traditionally seen as 'enemies' and are still highly reluctant to accept the potential transformation of Greek society into a multiethnic society.

In short, having in mind the importance of education in the formation of the national identity, we could say that the predominance of the ethnocentric national history in the Greek education system and in general the ethnocentric content of the books and the curricula in general may be one of the main reasons of the strong influence in Greek society of the Orthodox Church, of the anti-Western feeling and of the persistence of identitarian discourses like nationalism.

Nonetheless, we should be cautious when we make judgments about teaching from curricula and textbooks alone (Council of Europe, 1996). Brindle (1996) reminds us that 'we cannot assume that the content of the textbook is the same as the content of the lesson' (quoted in Goalen, 1997, p.2). Grosvenor (1999, pg. 248) argues that in order to come to some conclusion about the impact of the teaching in identity formation, we need to extend our vision of schooling to consider the cumulative effect of value messages in both the formal and 'hidden curriculum'.

In addition, if we are to interpret the persisting ethnocentric character of Greek national identity, we may need, as Chrysoloras (2004) argues, an alternative theoretical framework for the study of the national identity. Chrysoloras proposes a theoretical framework (radical ethnosymbolism) that incorporates elements from A.D. Smith's ethno-symbolism and from poststructuralist discourse theory (as it has been developed by the 'Essex school' of discourse analysis- Laclau \& Mouffe, Howarth, Norval, Stavrakakis, Glynos, et. al.) (2004, p. 2).

\section{Challenges for the national education systems in an era of economic and humanitarian crisis}

The future of the education systems is an issue all over the world. With the reality of everything changing so fast in Greece and within this context of financial crisis, multiple political and economical restructurings and uncertainty the educational scene is transforming rapidly and dramatically. Schools and universities are closing down; there are fewer teachers than needed in schools and fewer books and teaching materials. Teachers are very pessimistic; they feel undervalued because of the cutbacks in their salaries and their personal vision for education is being weakened day by day. This affects citizens particularly in the constitution of rights, responsibilities and identities (Robertson, 2008).

The severe complexity of issues surrounding nationality, immigration and asylum seekers, necessitates the need for new forms of identity that are more appropriate to these new times (Halpin \& Moore, 2006). If the schools 
are to meet the challenge of educating the next generation in a way that equips them for their contemporary life and for their future, then they must change (Johnson \& Hallgarten, 2002). However, the will for change alone is not enough. We have to think of what we need to change.

Research (Kiwan, 2008; Whitty, 2002; Steiner, 1994) suggests that if a society is to move towards a national education system that promotes an understanding of identity and diversity schools should:

- $\quad$ include a global perspective into the curriculum and teach in ways that encourage co- operation, critical thinking, democratic values of fairness and practices

- $\quad$ help students deal with prejudice and value diversity, develop selfesteem and a commitment to justice and sustainable development

- $\quad$ help students make connections between the abstract knowledge associated with subjects and students' own experiences in everyday life be committed to human rights

- $\quad$ actively seek to keep informed

- $\quad$ use a range of teaching styles

- $\quad$ encourage their students to be active and participate in the wider societal context

Maybe the above reformulations could be more possible if the education systems were to accept Mouffe's critiques of deliberative approaches to democracy, and base their reforms to her proposal for an agonisitc public sphere (Ruitenberg, 2008) and, as Norval (2000) argues, to a non-essentialist account of identity formation that wouldn't advantage the antagonistic over the differential dimension of identity.

Drawing upon the writings of Mouffe, we could say that such radical democratic citizenship education systems would aim 'to transform antagonism into agonism' (1995, p.108), and they would not be concerned with overcoming the 'us/them' distinction but with constructing the 'them' in such a way that it would no longer be perceived as an enemy to be destroyed, but as an 'adversary' whose existence is legitimate and must be tolerated' (2000, p. 101-102). Perhaps this kind of schools could meet the challenge of educating students in a way that would prepare them for their present and their future.

\section{Conclusion}

Appadurai some years ago (1996) argued that the very epoch of the nation-state is near its end and nationalism enters a terminal crisis. Today, we see that nationalism not only doesn't enter a terminal crisis but on the contrary in some countries is being revived. Even the most superficial examination of Modern Greek society reveals that the Greek nationalism is 
racist, anti-Western, ethnocentric and looks at everything from the national perspective, fact that jeopardizes national prosperity and democratic freedom (Beck, 2005); It also reveals that the latest political and economical changes has fuelled xenophobic backlash in Greece.

In our attempt to unravel the fact that Greece because of its persistent ethnocentrism expressed as exaggerated patriotism and xenophobia remains a largely pro- European country in which there is no room for cultural and social pluralism, we claimed that maybe the above has to do with the fact that the Greek nation state belongs to the ethnic model of the nations as well as with the nationalistic discourse and the narratives on which the construction of the Greek national identity is based.

People from countries that belong to the ethnic model of the nations construct their national identity by emphasizing the genealogy, the folk element, the native culture and language, customs, religions and rituals. As a result maybe they find difficulties in focusing on the world as a whole rather than on a particular locality or group within it (Calhoun, 2008), and in being patriotic- celebrating the institutions of the state which they live and at the same time cosmopolitan-celebrating the variety of human cultures and sharing the political culture of their state (Beck \& Sznaider, 2006; Couture \& Nielsen, 2005; Appiah, 1997).

In addition, we argued that the Greek national education system due to its capacity to shape national identities has played and continues to play significant role. The predominance of the ethnocentric national history in the Greek education system and the ethnocentric content of the books and the curricula are some of the main reasons why Greek national identity remains ethnocentric and resists to the construction of a European or a more cosmopolitan identity.

Drawing on the above conclusions we can contend that one of the most important challenges for the Greek government in the age of austerity is how to organise a quality education system that will address in its policy and curriculum documentation the full implications of the recent political and economical changes, will meet the needs of learners, parents and the community, will inspire conciliation and peace, will promote an understanding of identity and diversity, will construct a more tolerant conception of Greek national identity, will be committed to the cosmopolitan ideal (Held, 2005; McKinnon, 2005; Tan, 2005) and will 'transform antagonism into agonism' (Mouffe 1995, p.108).

\section{References:}

Amnesty International. (2011). Amnesty International Report 2011. The state of the world's human rights. [Online] Available at: 
http://allafrica.com/download/resource/main/main/idatcs/00020904:62e42cc 96e37b20d6d3f6750caf4e3dc.pdf (last accessed 5 May 2011).

Anderson, B. (1991). Imagined Communities, London and New York: Verso. Appadurai, A. (1996). Modernity at large. Cultural Dimensions of Globalization, Mineapolis: University of Minnesota Press.

Appiah, K. A. (1997). 'Cosmopolitan Patriots', Critical Theory, 23 (3), 617639.

Avdela, E. (1998). History and School, Athens: Nisos, (in Greek).

Barnett, R. (2008). 'Critical professionalism in an age of supercomplexity'. In Cunningham, B. (Ed.), Exploring Professionalism. Bedford Way Papers, Institute of Education, University of London.

Beck, U. (2000). 'Risk Society Revisited: Theory, Politics and Research Programmes'. In Adam, B., Beck, U. \& Van Loon, J. (Eds), The risk society and beyond. Critical issues for social theory, London: SAGE Publications. Beck, U. (2005). 'Re-Inventing Europe: A Cosmopolitan Vision', Quaderns de la Mediterrania [Online]. Available at: http://www.iemed.org/publicacions/quaderns/10/q10_109.pdf [last accessed 14 September 2011].

Beck, U. (2009). 'Critical Theory of World Risk Society: A cosmopolitan Vision’, Constellation, 16 (1), 33-22.

Beck, U. \& Sznaider, N. (2006). 'Unpacking cosmopolitanism for the social sciences: a research agenda', The British journal of Sociology, 57 (1), 1-23.

Brock, G. \& Brighouse, H. (2005), The Political Philosophy of Cosmopolitanism, Cambridge: Cambridge University Press.

Calhoun, C. (2008). 'Cosmopolitanism and nationalism', Nations and Nationalism, 14 (3), 427-448.

Chrysoloras, N. (2004). Religion and Nationalism in Greece, Second PanEuropean Conference, Standing Group on EU Politics, Bologna, 24-26 June 2004 [Online] Available at: http://www.jhubc.it/ecpr-bologna/docs/123.pdf (last accessed 16 May 2011).

Coulby, D. (2000). Beyond The National Curriculum. Curricular Centralism and Cultural Diversity in Europe and the USA, London: Routledge Falmer.

Coulby, D. (1997). "European Curricula, Xenophobia and Warfare", Comparative Education, 33 (1), 29-41. Blackwell.

Coulby, D. \& Jones C. (1995). Postmodernity and European Education Systems. Cultural diversity and centralist Knowledge, London: Tretham Books.

Council of Europe (1996). The Role of History in the Formation of National Identity, York, UK, 18-24 September 1995, DECS/SE/BS/Sem (95) 15, Strasbourg. 
Couture, J. \& Nielsen, K. (2005). 'Cosmopolitanism and the compatriot priority principle’. In Brock, G. \& Brighouse, H. (Eds), The Political Philosophy of Cosmopolitanism, Cambridge: Cambridge University Press.

Dimitrakopoulos, D. G. \& Passas, A. G. (2004). Greece in the European Union, London: Routlege.

Doxiadis, A. (Wed 22 June 2011). 'Please stop patronizing us Greeks', The Guardian [Online]. Available at: http://www.guardian.co.uk/commentisfree/2011/jun/22/greeks-economistseu [last accessed 29 September 2011].

EU-MIDIS (2009). European Union Minorities and Discrimination [Online]. Available at: http://fra.europa.eu/eu-midis/ [last accessed 19 March 2011]. Eurobarometer (2008). Discrimination in the European Union: Perceptions, Experiences and Attitudes [Online]. Available at: http://ec.europa.eu/public_opinion/archives/ebs/ebs_296_sum_en.pdf [last accessed 19 March 2011].

Eurydice. (2010). National system overviews on education systems in Europe and ongoing reforms. European commission [Online]. Available at: http://eacea.ec.europa.eu/education/eurydice/documents/eurybase/national_s ummary_sheets/047_EL_EN.pdf [last accessed 9 September 2011].

Ferro, M. (1984). The use and abuse of history: or how the past is taught, London: Routledge \& Kegan Paul.

Flouris, G. (1995). 'The image of Europe in the curriculum of the Greek elementary school'. In Bell, G. (Ed.) Educating European Citizens: Citizenship Values and the European Dimension, London: David Fulton.

Gellner, E. (1983). Nations and Nationalism, Oxford: Blackwell.

Goalen, P. (1997). 'History and national identity in the classroom', History Today, 47 (6), 6-8.

Goodings, R. (1987). "Becoming British: Inconspicuous Education for National Identity” in Gumbert, E. (1987). In the nation's Image: civic education in Japan, Soviet Union, the United States, France and Britain, USA: Centre for Cross-Cultural education.

Green, A. (1997). Education, Globalization and the nation state, London: The Macmillan Press.

Grovenor, I. (1999). “There's no place like home': education and the making of national identity”, History of Education, 28 (3), 235-250.

Guibernau, M. \& Goldblatt, D. (2000). 'Identity and Nation'. In Woodward, K. (Ed.) Questioning identity: gender, class, nation, London: Routledge.

Halpin, D. \& Moore, A. (2006). 'Educational Professionalism in an Age of Uncertainty: The Emergence of Eclectic \& Pragmatic Teacher Identities'. [Online]. Hitotsubashi Journal of Social Studies, 38 (2), 118-140. Available at: http://hdl.handle.net/10086/13802 [last accessed 28 September 2011]. 
Held, D. (2002). 'Cosmopolitanism: ideas, Realities and Deficits'. In Held, D. \& McGrew, A. (Ed), Governing Globalization. Power, Authority and Global Governance, Cambridge: Polity Press.

Held, D. (2005). 'Principles of cosmopolitan order'. In Brock, G. \& Brighouse, H. (Eds), The Political Philosophy of Cosmopolitanism, Cambridge: Cambridge University Press.

Hobsbawm, E.J. (1990). Nations and Nationalism since 1780 Programme, Myth, Reality, UK: Cambridge University Press.

International Association for the Evaluation of Educational Achievement (2011). International Civic and Citizenship Education Study - ICCS 2009 [Online]. Available at: http://www.iea.nl/icces.html\#c909 [last accessed 29 March 2011].

Johnson, M. \& Hallgarten, J. (2002). 'The future of the teaching profession'. In Johnson, M. \& Hallgarten, J. (Eds), From Victims of Change to Agents of Change: The future of the teaching profession. London: Institute for Public Policy Research.

Kaspersen, L. (2000). Classical and Modern Social Theory, Malden Massachusetts: Blackwell, pp. 447-466.

Kenway, J. \& Bullen, E. (2000). 'Education in the Age of Uncertainty: an eagle's eye-view'. Compare: A Journal of Comparative and International Education, 30 (3), 265-273.

Kiwan, D. (2008). Education for Inclusive Citizenship. London and New York: Routledge.

Kuzio, T. (2002). "The myth of the civic state: a critical survey of Hans Kohn's framework for understanding nationalism”, Ethnic and Racial Studies, 25 (1), 20-39.

Levitas, R. (2000). 'Discourses of Risk and Utopia'. In Adam, B., Beck, U. \& Van Loon, J. (Eds), The risk society and beyond. Critical issues for social theory, London: SAGE Publications.

Lynch, J. P. \& Simon, R. J. (2003). Immigration the World Over, United States of America: Powman \& Littlefield Publishers, inc.

Massialas, B. G \& Flouris, G. (1994). Education and the emerging concept of national identity in Greece. Paper presented at the Comparative and International Education Society, San Diego: Calif. March 21-24 1994.

McKinnon, C. (2005). 'Cosmopolitan hope'. In Brock, G. \& Brighouse, H. (Eds), The Political Philosophy of Cosmopolitanism, Cambridge: Cambridge University Press.

Mouffe, C. (2008). 'Which world order: cosmopolitan or multipolar?', Ethical Perspectives, 15 (4), 453-467.

Mouffe, C. (2000). The democratic paradox, London: Verso.

Mouffe, C. (1995). 'Politics, democratic action, and solidarity', Inquiry, 38 (1-2), 99-108. 
Norval, A. J. (2000). 'Trajectories of future research in discourse theory'. In Howarth, D., Norval, A. J. \& Stavrakakis, Y. (Eds), Discourse theory and political analysis, Manchester: Manchester University Press.

Ostergaard, U. (2000). 'State, Nation and National Identity'. In Andersen, H.,

Robertson, S. L. (2008), 'Globalization, Education Governance, and Citizenship Regimes. New Democratic Deficits and Social Injustices'. In Ayers, W., Quinn, T. \& Stoval, D. (Eds), Handbook of social justice in education, London: Routlege.

Pappas, T. S. (2010). 'The causes of the Greek crisis are in Greek politics', OpenEconomy- Open-minded economics, 29 November 2010, http://www.opendemocracy.net/openeconomy/takis-s-pappas/causes-ofgreek-crisis-are-in-greek-politicst fiscal crisis [last accessed 28 September 2011].

Romanias, G. (Sat December $28^{\text {th }}$, 2009). 'The consequences of the crisis and the development of the unemployment in our country', Newspaper: Vima, pg. 25 (in Greek).

Rozakis, C. L. (2001). 'Nationality Law in Greece'. In Hansen, R. \& Weil, P. (Eds), Towards a European Nationality, Citizenship, Immigration and Nationality Law in the EU, New York: Palgrave.

Ruitenberg, C. (2008). 'Educating Political Adversaries. Chantal Mouffe and radical democratic citizenship education', Studies in Philosophy and Education, 28 (3), 269-281.

Shulman, S. (2002). "Challenging the Civic/Ethnic and West/East dichotomies in the study of nationalism", Comparative Political Studies, 35 (5), 554-585.

Smith, A.D. (1991). National Identity, London: Penguin Books.

Smith, A.D. (2000). 'National Identity and the idea of European Unity'. In Gowan, P. \& Anderso, P. (Eds), The Question of Europe, London: Verso.

Steiner, M. (1994). Developing the Global Teacher. Stoke-on-Trent: Trentham Books.

Stamelos, G. (2000). 'Preface'. In De Queiroz J. M., The School and its Sociologies, Athens: Gutenberg, (in Greek).

Stratoudaki, C. (2008). Studies for the immigrants in Greece. Working Papers 2008/20, Athens: National Center for Social Research, (in Greek).

Tan, K. (2005). 'The demands of justice and national allegiances'. In Brock, G. \& Brighouse, H. (Eds), The Political Philosophy of Cosmopolitanism, Cambridge: Cambridge University Press.

Tilly, C. (1992). Coercion, Capital and European States, AD 990-1992, Cambridge MA \& Oxford: Blackwell.

Tsoukalas, K. (1982). Dependence and Reproduction. The social role of the education system in Greece (1830-1922), Athens: Themelio, (in Greek). 
Vayanos, D., Meghir, C., Vettas, N. (2010). 'The economic crisis in Greece: A time of reform and opportunity', Greek Economist for reform.com, http://greekeconomistsforreform.com/public-finance/the-economic-crisis-ingreece-a-time-of-reform-and-opportunity-2/ [last accessed 28 September 2011].

Wiborg, S. (2000). "Political and Cultural Nationalism in Education. The ideas of Rousseau and Herder concerning national education", Comparative Education, 36 (2), 235-243.

Whitty, G. (2002). 'Re-forming teacher professionalism for new times'. In Making Sense of Education Policy. London: Paul Chapman. 